\title{
IMMUNOHISTOCHEMICAL PROFILE OF INFILTRATING DUCTAL CARCINOMA BREAST- PROGNOSTIC AND THERAPEUTIC USE
}

\author{
${ }^{1}$ Assistant Professor, Department of Surgery, GMC, Patiala. \\ ${ }^{2}$ Associate Professor, Department of Surgery, GMC, Patiala. \\ ${ }^{3}$ Lecturer, Department of Pathology, GMC, Patiala. \\ ${ }^{4}$ Senior Resident, Department of Surgery, GMC, Patiala. \\ 5Junior Resident, Department of Pathology, GMC, Patiala.
}

Prem Chand ${ }^{1}$, Ashok Kumar2, Vandana Singla ${ }^{3}$, Goldendeep Singh ${ }^{4}$, Ramandeep 5

ABSTRACT

\section{BACKGROUND}

Breast carcinoma is the most common malignant tumour and the leading cause of death in women. Various prognostic and predictive factors are used in the management of breast cancer. Oestrogen receptor (ER), progesterone receptor (PR) \& human epidermal growth receptor (HER2/neu) are prognostic as well as predictive factors.

The aim of the present study was conducted to evaluate ER, PR \& HER2/neu expression in invasive ductal carcinoma of the breast (not otherwise specified) by immunohistochemistry to explore the correlation of these markers to each other, as well as to various clinicopathological parameters like age of patient, histological grade, tumour size and lymph node metastasis.

\section{MATERIALS AND METHODS}

100 cases of infiltrating ductal carcinoma (NOS) were taken. Slides were prepared from paraffin blocks containing cancer tissue of these patients \& immunohistochemical staining was done for ER, PR, and HER2/neu expressions. Interpretation of expressions done using Allred scoring system for ER/PR \& ASCO/CAP guidelines for HER2/neu. Statistical analysis was done to determine the statistical significance by applying chi-square test.

\section{RESULTS}

In our study, mean age was 55.28 years. Average tumour size was $4.3 \mathrm{~cm} \&$ majority of tumours were grade II. 38 patients had axillary lymph nodes positive for metastasis. 58 cases were both ER \& PR positive and 37 cases ER/PR negative. Only 7 were HER2/neu positive \& 93 were HER2/neu negative. Only 2 cases were both ER as well as HER2/neu positive, 32 cases were both ER \& HER2/neu negative. 66 cases showed different expressions of ER \& HER/neu. ER \& PR correlated significantly with age, tumour size, and tumour grade; whereas HER2/neu correlated significantly with age \& tumour size only. No association was seen with axillary lymph node metastasis. ER and PR expression correlated with each other, but none was correlated with HER2/neu.

\section{CONCLUSION}

Assessment of hormone receptors for clinical management of a breast cancer patient is strongly recommended to provide prognostic information and therapeutic options.

\section{KEYWORDS}

Infiltrating Ductal Carcinoma, Immunohistochemical Markers, Oestrogen Receptors, Progesterone Receptors, Human Epidermal Growth Factor.

HOW TO CITE THIS ARTICLE: Chand P, Kumar A, Singla V, et al. Immunohistochemical profile of infiltrating ductal carcinoma breast- Prognostic and therapeutic use. J. Evolution Med. Dent. Sci. 2017;6(21):1695-1700, DOI: 10.14260/Jemds/2017/373

\begin{abstract}
BACKGROUND
Breast carcinoma is the most common malignant tumour and the leading cause of deaths due to carcinoma in women. ${ }^{[1]}$ In India, breast cancer is the second most common cancer (after cervical cancer) \& second most common cause of cancerrelated deaths among women.[2] There are so many types of breast carcinomas, but infiltrating ductal carcinoma is most common histological type of breast cancer.[3] The infiltrating ductal carcinoma term is used for all breast carcinomas that cannot be subclassified into one of the specialised types.
\end{abstract}

Financial or Other, Competing Interest: None.

Submission 02-02-2017, Peer Review 27-02-2017,

Acceptance 04-03-2016, Published 13-03-2017.

Corresponding Author:

Dr. Prem Chand,

\#108-Hem Bagh, Near Shiv Mandir,

Kheri Gujjran Road, Patiala-147001, Punjab.

E-mail: premchandsingl@gmail.com

DOI: $10.14260 /$ jemds $/ 2017 / 373$
Carcinomas of "no special type" or "not otherwise specified"(NOS) are synonyms for ductal carcinomas. Traditional morphological prognostic factors include tumour size, tumour grade, axillary lymph node metastasis, etc. Now a days, more importance is given to biological molecular prognostic factors, because a significant number of patients with early stage breast cancer harbour microscopic metastasis at the time of diagnosis.

Prognostic and predictive factors are used in the management of breast cancer. Prognostic factors are those which evaluate patient's overall outcome such as chances of recurrence after treatment. These factors help in selection of patients for a specific treatment. ${ }^{[4]}$ Predictive factors evaluate the likelihood of benefit from a specific treatment. ER, PR \& HER2/neu are prognostic as well as predictive factors.[4]

\section{Oestrogen Receptor}

The oestrogen receptor plays a very important role in the pathophysiology of breast cancer. Oestrogen receptor is of two types- ER $\alpha$ and ER $\beta$. Receptor ER $\alpha$ is a well-established 
prognostic and predictive factor in breast cancer. The prognostic significance of ER $\beta$ is not well defined.[5],[6] The majority of ER-positive breast cancers contain both ER $\alpha$ and ER $\beta$ subtypes, although some cancers have only ER $\beta$ expression. This may lead to distinct clinical behaviours and responses. It is observed that in contrast to $\mathrm{ER} \alpha, \mathrm{ER} \beta$ expression declines during breast carcinogenesis.[7],[8]

\section{Progesterone Receptor}

Progesterone receptor is of two types: PR-A \& PR-B. Progesterone acts as a modulator of oestrogen function.[9],[10] PR expression increases, as the atypia in breast tissue, increases. It is observed that ER-positive breast cancers which lack PR expression, are less responsive to hormonal treatment than those that are PR positive. It is also seen that ER \& PR are not stable phenotypes. These can change the natural history of the disease or as consequence of treatment.[11] HER2/neu (c-erbB-2).

It is a member of four member family of closely related growth factor receptors, including EGFR or HER1, HER2, HER3, HER4. HER2/neu amplification or over expression is involved in oncogenic transformation and tumorigenesis in breast cancer. Inappropriately increased signalling occurs as a result of receptor over-expression. It may lead to increased \& uncontrolled cell proliferation, decreased apoptosis, increased cancer cell motility and angiogenesis and hence worse prognosis.[12]

The present study was conducted to correlate the expression of ER, PR \& HER2/neu with each other \& to various clinicopathological parameters.

\section{MATERIAL AND METHODS}

\section{Study Design}

This study was conducted on 100 Patients, of infiltrating ductal carcinoma breast (NOS) to analyse the expression of ER, PR, and HER2/neu by immunohistochemistry.

\section{Specimen Selection}

\section{Inclusion Criteria}

Histopathologically diagnosed cases of IDC-NOS.

\section{Exclusion Criteria}

1. Histopathological subtypes other than IDC-NOS.

2. Patients who received neo-adjuvant chemotherapy.

3. Inflammatory breast lesions.

4. Post-traumatic breast lesions.

5. Benign breast diseases.

\section{Immunohistochemistry Procedure}

From histologically confirmed cases of infiltrating ductal carcinoma breast (nos.), paraffin blocks containing cancer tissue were selected. Slides were prepared from these paraffin blocks. Standard procedure was followed for immunohistochemical staining of slides for ER, PR, and HER2/neu.[13]

\section{Procedure \\ Preparation of Paraffin Slides}

Paraffin sections were cut at 5 micrometres, mounted on silanized slides, and melted at $65^{\circ} \mathrm{C}$ in an oven for 2 hours. Slides were dipped into xylene ( 3 times) for 5 minutes each to remove the paraffin. Tissues were dehydrated by dipping the slides into absolute ethanol (100\%), then 95\% ethanol, and finally $70 \%$ ethanol. Slides were washed with distilled water for $5 \mathrm{~min}$. \& then dipped into a fresh aqueous solution of $3 \%$ peroxide for $3 \mathrm{~min}$. and then rinsed with Tris buffer for 3 minutes.

\section{Antigen Retrieval (In Decloaking Chamber)}

Heat retrieval was done with citrate buffer in Decloaking chamber for forty minutes at $95^{\circ} \mathrm{C} \&$ then brought to room temperature after removing from Decloaking chamber and by placing the slides in Tris-Saline buffer.

\section{Detection of Antigens in Paraffin Sections}

1\% Mouse serum (Diluted in antibody dilution buffer) was added to the tissue section for 20 minutes, to block non-specific immunostaining.

The primary antibody was added and the sections are exposed to the primary antibody, usually for one hour \& primary antibody was washed from slide with Tris buffer. Sections were soaked in Tris buffer for 10 minutes (2X 5 min. washes).

\section{Secondary Detection of the Primary Antibody}

Sections were then incubated with biotinylated mouse anti-species antibody for 10 minutes. Sections were rinsed for $10 \mathrm{~min}$ (2X $5 \mathrm{~min}$. washes) in Tris buffer. A solution of chromogen, 3,3'-diaminobenzidine (DAB) at $1 \mathrm{mg} / \mathrm{mL}$ in Tris buffer with $0.016 \%$ fresh $\mathrm{H}_{2} \mathrm{O}_{2}$ was made \& added to the slides and incubated for approximately 8 minutes. DAB from the slides was washed with tap water.

\section{Counterstaining}

Slides were dipped in a solution of haematoxylin that is diluted 1:1 in distilled water and stained for one minute to produce a very light nuclear counterstaining. Washed for 1 min. in distilled water \& dehydrated by dipping in $95 \%$ ethanol for $1 \mathrm{~min}$., then $100 \%$ ethanol for $1 \mathrm{~min}$. Washed 3 times in xylene and cover slip applied for viewing \& reporting.

\section{Reporting}

ER/PR scoring system and criteria as per Allred scoring system[14]: Figure 1.

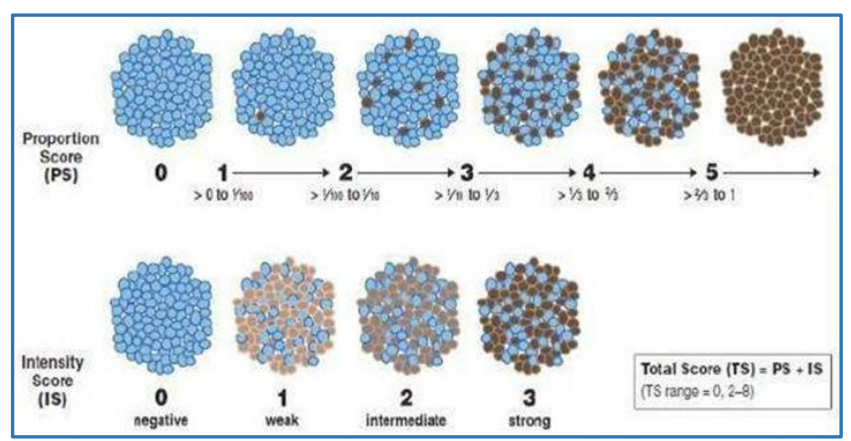

Figure 1. Allred Scoring System

\footnotetext{
Proportion Score

0 - No cells are ER +ve.

$1-\leq 1 \%$ of cells are ER +ve.

$2-1-10 \%$ of cells are ER +ve.

$3-11-33 \%$ of cells are ER +ve.

$4-34-66 \%$ of cells are ER +ve.

$5-67-100 \%$ of cells are ER +ve.
} 
Intensity Score

0 - Negative.

1 - Weak.

2 - Intermediate.

3 - Strong.

\section{Interpretation}

Total (proportion score + intensity score)

0-2=Negative; $3-8=$ Positive.

HER2/neu Scoring System and Criteria According to ASCO-CAP Guidelines [15]

$0=$ No staining or incomplete faint and barely perceptible in $<10 \%$ of tumour cells. $1+=$ Incomplete membrane staining which is faint and barely perceptible and within $>10 \%$ of tumour cells.

$2+=$ Circumferential membrane staining that is incomplete and/or weak/moderate and within $>10 \%$ of the invasive tumour cells; or complete and circumferential membrane staining that is intense and within $\leq 10 \%$ of the invasive tumour cells.
$3+=$ Circumferential, complete and intense staining and within $>10 \%$ of tumour cells.

FISH is required for equivocal HER2/neu positivity. So, HER2/neu 2+ was taken as negative along with HER2/neu 0 and $1+$. Only $3+$ on IHC was taken as positive.

\section{Statistical Analysis}

Chi-square test was used to determine the statistical significance between ER/PR status and HER2/neu status along with their correlation with various clinicopathological parameters like patient's age, axillary lymph node status, tumour size and tumour grade with respect to IDC-NOS. A p value of $<0.05$ was considered statistically significant.

\section{RESULTS}

Age

In our study, the mean age was 55.28 years. The majority of ER-positive $(96.82 \%)$ cases were of age $>40$ years and $44.44 \%$ were of age $>60$ years. The majority of PR-positive $(96.55 \%)$ cases were of age $>40$ years and $43.10 \%$ were of age $>60$ years. The majority of HER2/neu positive $(71.43 \%)$ were of age $<40$ years i.e. younger age group (Table-1).

\begin{tabular}{|c|c|c|c|c|c|c|c|c|c|}
\hline \multirow{2}{*}{ Age Group (Years) } & \multicolumn{4}{|c|}{ ER } & \multicolumn{4}{c|}{ PR } & \multicolumn{3}{c|}{ HER2/neu } \\
\cline { 2 - 11 } & Positive & Negative & Total & Positive & Negative & Total & Positive & Negative & Total \\
\hline$<40$ & 02 & 13 & 15 & 02 & 13 & 15 & 05 & 10 & 15 \\
\hline $41-50$ & 09 & 10 & 19 & 09 & 10 & 19 & 01 & 18 & 19 \\
\hline $51-60$ & 24 & 08 & 32 & 22 & 10 & 32 & 01 & 31 & 32 \\
\hline$>60$ & 28 & 06 & 34 & 25 & 09 & 34 & 00 & 34 & 34 \\
\hline Total & $\mathbf{6 3}$ & $\mathbf{3 7}$ & $\mathbf{1 0 0}$ & $\mathbf{5 8}$ & $\mathbf{4 2}$ & $\mathbf{1 0 0}$ & $\mathbf{0 7}$ & $\mathbf{9 3}$ & $\mathbf{1 0 0}$ \\
\hline \multicolumn{8}{|c|}{ Table 1. ER \& PR Expression compared to Age } \\
\hline
\end{tabular}

Using chi-square statistics, it was observed that various values for ER expression were $x^{2}=25.305 ; \mathrm{df}=3 ; \mathrm{p}=0.000$, for PR expression were $\mathrm{x}^{2}=18.051 ; \mathrm{df}=3 ; \mathrm{p}=0.000$; \& for HER2/neu expression $x^{2}=19.363 ; \mathrm{df}=3 ; \mathrm{p}=0.000 \&$ it was concluded that ER, PR\& HER2/neu expression compared to age distribution was statistically highly significant.

\section{Axillary lymph Node Status}

38 patients had axillary lymph nodes positive for metastasis. Out of 63 ER-positive cases, 25 had positive axillary lymph nodes, whereas out of 58 PR-positive cases 23 had positive axillary lymph nodes, and out of 7 HER2/neu-positive cases, 2 had positive axillary lymph nodes. (Table 2 ).

\begin{tabular}{|c|c|c|c|c|c|c|c|c|c|}
\hline \multirow{2}{*}{$\begin{array}{l}\text { Axillary Lymph } \\
\text { Node Status }\end{array}$} & \multicolumn{3}{|c|}{ ER } & \multicolumn{3}{|c|}{ PR } & \multicolumn{3}{|c|}{ HER2/neu } \\
\hline & Positive & Negative & Total & Positive & Negative & Total & Positive & Negative & Total \\
\hline Positive & 25 & 13 & 38 & 23 & 15 & 38 & 02 & 36 & 38 \\
\hline Negative & 38 & 24 & 62 & 35 & 27 & 62 & 05 & 57 & 62 \\
\hline Total & 63 & 37 & 100 & 58 & 42 & 100 & 07 & 93 & 100 \\
\hline
\end{tabular}

Using chi-square statistics, various values for ER expression were $\mathrm{x}^{2}=0.205 ; \mathrm{df}=1 ; \mathrm{p}=0.651$; for $\mathrm{PR}$ expression were $\mathrm{x}^{2}=0.161 ; \mathrm{df}=1 ; \mathrm{p}=0.689$ \& HER $2 / \mathrm{neu}$ expression were $x^{2}=0.284 ; \mathrm{df}=1 ; \mathrm{p}=0.594$; It was concluded that axillary lymph node status with ER, PR and HER2/neu was not statistically significant.

\section{Tumour Size}

Tumour size was highly variable ranging from $0.1 \mathrm{~cm}$ to 12 $\mathrm{cm}$. The average tumour size was $4.3 \mathrm{~cm}$. The majority of ER/PR positive (46-47\%) tumours were of size between 2 to $5 \mathrm{~cm} \mathrm{\&} \mathrm{majority} \mathrm{of} \mathrm{HER2/neu} \mathrm{positive}(71.43 \%)$ tumours were of size $<2 \mathrm{~cm}$. (Table- 3 ).

\begin{tabular}{|c|c|c|c|c|c|c|c|c|c|}
\hline \multirow{2}{*}{ Tumour Size (cm) } & \multicolumn{3}{c|}{ PR } & \multicolumn{3}{c|}{ HER2/neu } \\
\cline { 2 - 10 } & Positive & Negative & Total & Positive & Negative & Total & Positive & Negative & Total \\
\hline$<2$ & 23 & 06 & 29 & 21 & 08 & 29 & 05 & 24 & 29 \\
\hline $2-5$ & 30 & 13 & 43 & 27 & 16 & 43 & 02 & 41 & 43 \\
\hline$>5$ & 10 & 18 & 28 & 10 & 18 & 28 & 00 & 28 & 28 \\
\hline Total & $\mathbf{6 3}$ & $\mathbf{3 7}$ & $\mathbf{1 0 0}$ & $\mathbf{5 8}$ & $\mathbf{4 2}$ & $\mathbf{1 0 0}$ & $\mathbf{0 7}$ & $\mathbf{9 3}$ & $\mathbf{1 0 0}$ \\
\hline \multicolumn{8}{|c}{ Table 3. ER, PR \& HER2/neu Expression compared to Tumour Size } \\
\hline
\end{tabular}


Using chi-square statistics, expression of ER compared to tumour size was $x^{2}=3.098 ; \mathrm{df}=2 ; \mathrm{p}=0.001$; expression of $\mathrm{PR}$ was $\mathrm{x}^{2}=8.587 ; \mathrm{df}=2 ; \mathrm{p}=0.014 ; \&$ expression of HER2/neu was $\mathrm{x}^{2}=7.144 ; \mathrm{df}=2 ; \mathrm{p}=0.028$. So it was concluded that expression of ER, PR\& HER2/neu compared to tumour size was statistically significant.

\section{Tumour Grade}

\begin{tabular}{|c|c|c|c|c|c|c|c|c|c|}
\hline Tumour Grade & \multicolumn{3}{|c|}{ ER } & \multicolumn{3}{c|}{ PR } & \multicolumn{3}{c|}{ HER2/neu } \\
\hline & Positive & Negative & Total & Positive & Negative & Total & Positive & Negative & Total \\
\hline Grade I & 20 & 06 & 26 & 18 & 08 & 26 & 01 & 25 & 26 \\
\hline Grade II & 31 & 12 & 43 & 28 & 15 & 43 & 02 & 41 & 43 \\
\hline Grade III & 12 & 19 & 31 & 12 & 19 & 31 & 04 & 27 & 31 \\
\hline Total & $\mathbf{6 3}$ & $\mathbf{3 7}$ & $\mathbf{1 0 0}$ & $\mathbf{5 8}$ & $\mathbf{4 2}$ & $\mathbf{1 0 0}$ & $\mathbf{0 7}$ & $\mathbf{9 3}$ & $\mathbf{1 0 0}$ \\
\hline \multicolumn{8}{|c|}{ Table 4. ER, PR\& HER2/neu Expression compared to Tumour Grade } \\
\hline
\end{tabular}

In our study, according to Nottingham Modified BloomRichardson system (MBR) score, majority tumours were in grade II (43\%), followed by grade III (31\%) and then grade I (26\%). The majority of ER/PR positive (48-49\%) tumours were of grade II \& majority of HER2/neu positive (57.14\%) tumours were of grade III.

Using chi-square statistics, it was seen that expression of ER compared to tumour grade was $\mathrm{x}^{2}=11.534 ; \mathrm{df}=2 ; \mathrm{p}=$ 0.003; expression of PR was $\mathrm{x}^{2}=6.976 ; \mathrm{df}=2 ; \mathrm{p}=0.031$ \& expression of HER2/neu was $x^{2}=2.421 ; d f=2 ; p=0.298$. It was concluded that expression of ER/PR compared to tumour grade was statistically significant \& HER2/neu was not significant.

\section{Oestrogen Receptor Status}

Majority (63\%) of tumours were ER positive and 37\% were ER negative. ER-positive tumours showed weak, moderate to strong nuclear positivity in $>1 \%$ of tumour cells.

\section{Progesterone Receptor Status}

58 tumours were PR Positive and 42 were PR negative. PRpositive cases showed weak, moderate to strong nuclear positivity in $>1 \%$ of tumour cells.

\begin{tabular}{|c|c|c|c|}
\hline ER/PR & PR Positive & PR Negative & Total \\
\hline ER Positive & 58 & 5 & 63 \\
\hline ER Negative & 0 & 37 & 37 \\
\hline Total & $\mathbf{5 8}$ & $\mathbf{4 2}$ & $\mathbf{1 0 0}$ \\
\hline Table 5. ER Expression compared to PR Expression \\
\hline
\end{tabular}

Kappa value $=0.854 ;$ ASE $=0.053 ; \mathrm{p}$ value $=0.000$

Out of 100 cases, 58 cases were ER \& PR positive, 37 cases negative \& 5 cases showed different expressions of ER \& PR. (Table 5). On statistical analysis using kappa as measure of agreement, it is concluded that expressions of ER \& PR agree significantly to each other.

\section{HER2/neu Expression}

Only 7 were HER2/neu positive and 93 were HER2/neu negative.

\begin{tabular}{|c|c|c|c|c|c|c|c|}
\hline $\begin{array}{c}\text { ER/ } \\
\text { HER2/neu }\end{array}$ & $\begin{array}{l}\text { HER2/neu } \\
\text { Positive }\end{array}$ & $\begin{array}{c}\text { HER2/neu } \\
\text { Negative }\end{array}$ & Total & $\begin{array}{c}\text { PR/ } \\
\text { HER2/neu }\end{array}$ & $\begin{array}{c}\text { HER2/neu } \\
\text { Positive }\end{array}$ & $\begin{array}{l}\text { HER2/neu } \\
\text { Negative }\end{array}$ & Total \\
\hline ER Positive & 02 & 61 & 63 & PR Positive & 02 & 56 & 58 \\
\hline ER Negative & 05 & 32 & 37 & PR Negative & 05 & 37 & 42 \\
\hline Total & 07 & 93 & 100 & Total & 07 & 93 & 100 \\
\hline
\end{tabular}

Kappa value $=-0.079 ; \mathrm{ASE}=0.048 ; \mathrm{p}$ value $=0.058[\mathrm{ER}$ compared to HER2/neu].

Only 2 cases were ER, PR as well as HER2/neu positive. 32 cases were both ER \& HER2/neu negative. Majority i.e. 66 cases showed different expressions of ER \& HER2/neu (Table 6). On statistical analysis using kappa as a measure of agreement, it is concluded that expressions of ER \& HER2/neu do not agree to each other.

\section{DISCUSSION}

Breast cancer is the most common malignancy in women. It is highly curable, if diagnosed at early stage, because a significant number of patients with early stage breast cancer harbour microscopic metastasis at the time of diagnosis. Prognostic and predictive factors are used in the management of breast cancer. ER, PR \& HER2/neu are prognostic as well as predictive factors. Correlation of the expression of ER, PR \& HER2/neu with each other \& to various clinicopathological parameters is significant.
Age

Patients were in age group between 24 and 80 years. The mean age was 55.28 years. Studies conducted by Kaul R et al[16] showed similar results. In the present study, majority of ER-positive $(44.44 \%)$ and PR positive $(43.10 \%)$ cases were of age $>60$ years. Studies conducted by Onitilo AA et al[17] Alzaman AS et al[18] showed similar results. The majority of HER2/neu positive $(71.43 \%)$ were of age $<40$ years in the present study. Studies conducted by Alzaman AS et al[18] showed similar results.

There was significant correlation seen between the age of the patient and ER $(p=0.000) \&$ PR $(p=0.000)$ expression in present study. Studies by Dodiya $\mathrm{H}$ et al[19] and Ghosh $\mathrm{S}$ et al[20] showed similar results. Significant correlation was also observed between age of the patient and HER2/neu expression $(p=0.000)$, similar to studies conducted by Ramic $\mathrm{S}$ et al[21] and Ganesan $\mathrm{M}$ et al.[22] 


\section{Axillary Lymph Node Status}

$38 \%$ patients had axillary lymph nodes positive for metastasis. $39.68 \%$ of ER-positive cases had positive axillary lymph nodes for metastasis. $39.65 \%$ of PR-positive cases had positive axillary lymph nodes. $28.57 \%$ of HER2/neu-positive cases had positive axillary lymph nodes for metastasis. A study conducted by Ali EM et al[23] showed similar results. There was no significant correlation observed between axillary lymph node status with ER $(\mathrm{p}=0.651)$, PR ( $\mathrm{p}=$ $0.689)$ and HER $2 /$ neu ( $p=0.594)$ expression in present study, similar to studies conducted by Azizun Nisa et al.[24]

\section{Tumour}

Tumour size was $0.1 \mathrm{~cm}$ to $12 \mathrm{~cm}$, with average size $4.3 \mathrm{~cm}$. The majority of cases (43\%) had size 2 to $5 \mathrm{~cm}$, similar to Siadati $\mathrm{S}$ et al[25]study. $47.61 \%$ of ER-positive \& $46.55 \%$ of PR-positive tumours were of size 2 to $5 \mathrm{~cm}$. $71.43 \%$ of HER2/neu tumours were of size $<2 \mathrm{~cm}$. A study conducted by Prasad HLK et al[26] showed similar results.

There was significant correlation seen between tumour size and ER ( $\mathrm{p}=0.001)$, PR ( $\mathrm{p}=0.014)$ expression in present study. Studies by Prasad HLK et al[26] showed similar results. Similar to Almasri NM et al[27] study, significant correlation was seen between tumour size and HER2/neu expression ( $p$ $=0.028)$.

\section{Tumour Grade}

In the present study, majority of tumours were in grade II (43\%) followed by grade III (31\%) and then grade I (26\%). The majority of ER-positive (49.21\%) and majority of PRpositive $(31.03 \%)$ tumours were of grade II, but majority of HER2/neu-positive (57.14\%) tumours were of grade III, similar to study conducted by Siadati S et al.[25] There was significant correlation of tumour grade with ER $(p=0.003)$ \& PR ( $p=0.031)$, similar to study done by Onitilo AA et al[17] and Dodiya $\mathrm{H}$ et al.[19] As shown by Dodiya $\mathrm{H}$ et al,[19] no association was seen between tumour grade and HER2/neu expression $(\mathrm{p}=0.298)$.

\section{Receptor Positivity}

Majority (63\%) of tumours were ER positive and 37\% were ER-negative. 57\% tumours were PR Positive and 43\% were PR negative. Only 7\% were HER2/neu positive and $93 \%$ were HER2/neu negative.

There was wide variation seen in the ER, PR \& HER2/neu expression in breast carcinoma in different studies, possibly due to variations in different populations. In the present study, ER positivity was $63 \%$, closely matched the results of the study conducted by Idirisinghe PK et al[28] \& PR-positivity was $58 \%$, closely matched the results of the study conducted by Engstrom MJ et al.[29] HER2/neu positivity was only 7\%, much lower as compared to other studies. The possible explanation for this is due to variations in different populations. Also, HER2/neu assay results are influenced by multiple biologic, technical and performance factors. Since many aspects of HER2/neu assays have not been standardised, the effects of these disparate influences could not be isolated.

ER and PR correlated with each other $(p=0.000)$, whereas expression of HER2/neu was inversely related to ER $(p=0.058) \&$ PR expression $(p=0.102)$. Similar results were found in studies conducted by Siadati $S$ et al,[25] Maha A et al,[30] etc.

\section{CONCLUSION}

Invasive ductal carcinomas of breast were seen in age of 24 to 80 years, with mean age of 55.28 years. The maximum number of cases were seen in the age of $>50$ years $(66 \%)$. The majority of tumours were ER \& PR positive and HER2/neu negative. The majority of ER \& PR positive tumours were of grade II; whereas majority of HER2/neu-positive tumours were of grade III. The present study confirmed that ER \& PR correlated significantly with age, tumour size and tumour grade; whereas HER2/neu correlated significantly with age \& tumour size only. No association was seen with axillary lymph node metastasis. ER and PR expression correlated with each other, but none was correlated with HER2/neu.

Assessment of hormone receptors for clinical management of breast cancer patients is strongly recommended to provide prognostic information and therapeutic options.

\section{REFERENCES}

[1] Rosai J. Rosai and Ackerman's surgical pathology. 10 $0^{\text {th }}$ edn. Vol: 2. St. Louis, USA: Elsevier Mosby 2011:1681722.

[2] Dhillon PK. Breast cancer factsheet. South Asia network for chronic disease, public health foundation of India. Available at: www.sancd.org/Breast $\% 20$ cancer $\% 20$ factsheet $\% 200$ 3.11.11.pdf.

[3] Kumar V, Abbas AK, Aster JC. Robbins and Cotran pathologic basis of disease. 9th edn. Vol: 2 . Philadelphia, USA: Elsevier Saunders 2014:1051-68.

[4] Mehta S, Shelling A, Muthukaruppan A, et al. Predictive and prognostic molecular markers for cancer medicine. Ther Adv Med Oncol 2010;2(2):125-48.

[5] Speirs V, Kerin MJ. Prognostic significance of oestrogen receptor beta in breast cancer. Br J Surg 2000;87(4):405-9.

[6] Dotzlaw H, Leygue E, Watson PH, et al. Estrogen receptor-beta messenger RNA expression in human breast tumor biopsies: relationship to steroid receptor status and regulation by progestins. Cancer Res 1999;59(3):529-32.

[7] Skliris GP, Munot K, Bell SM, et al. Reduced expression of oestrogen receptor beta in invasive breast cancer and its re-expression using DNA methyl transferase inhibitors in a cell line model. J Pathol 2003;201(2):213-20.

[8] Hartman J, Strom A, Gustafsson JA. Estrogen receptor beta in breast cancer-diagnostic and therapeutic implications. Steroids 2009;74(8):635-41.

[9] Giangrande PH, McDonnell DP. The A \& B isoforms of human progesterone receptor: two functionally different transcription factors encoded by a single gene. Recent Prog Horm Res 1999;54:291-313.

[10] McDonnell DP, Shahbaz MM, Vageto E, et al. The human progesterone receptor A-form functions as a transcriptional modulator of mineralocorticoid receptor transcriptional activity. J Steroid Biochem Mol Biol 1994;48(5-6):425-32.

[11] Allred DC, Mohsin SK, Fuqua SA. Histological and biological evolution of human premalignant breast disease. Endocr Relat Cancer 2001;8(1):47-61. 
[12] Prenzel N, Fischer OM, Streit S, et al. The epidermal growth factor receptor family as a central element for cellular signal transduction and diversification. Endocr Relat Cancer 2001;8(1):11-31.

[13] Immunohistochemistry standard operating protocol. Available at: http:/edrn.nci.gov/resources/standardoperating procedures/assays/IHC/immunoperoxidase staining/sop-ihc.

[14] Allred DC, Harvey JM, Berardo M, et al. Prognostic and predictive factors in breast cancer by immunohistochemical analysis. Mod Pathol 1998;11(2):155-68.

[15] ASCO-CAP HER2/neu test guideline recommendations. College of American Pathologists 2013.

[16] Kaul R, Sharma J, Minhas SS, et al. Hormonal receptor status of breast cancer in the Himalayan region of Northern India. Indian J Surg 2011;73(1):9-12.

[17] Onitilo AA, Engel JM, Greenlee RT, et al. Breast cancer subtypes based on ER/PR and HER2 expression: comparison of clinicopathologic features and survival. Clin Med Res 2009;7(1-2):4-13.

[18] Alzaman AS, Mughal SA, Alzaman YS, et al. Correlation between hormone receptor status and age, and its prognostic implications in breast cancer patients in Bahrain. Saudi Med J 2016;37(1):37-42.

[19] Dodiya H, Patel A, Patel D, et al. Study of hormone receptors and epidermal growth factor expression in invasive breast cancers in a cohort of Western India. Indian J Clin Biochem 2013;28(4):403-9.

[20] Ghosh S, Sarkar S, Simhareddy S, et al. Clinicomorphological profile and receptor status in breast cancer patients in a South Indian institution. Asian Pac J Cancer Prev 2014;15(18):7839-42.

[21] Ramic S, Asic K, Balja MP, et al. Correlation of phosphorylated HER2 with clinicopathological characteristics and efficacy of transtuzumab treatment of breast cancer. Anticancer Res 2013;33(6):2509-15.

[22] Ganesan M, Kadalmani B. A retrospective analysis of incidence of breast cancer at a tertiary care hospital in South India. Journal of Academia and Industrial Research 2016;4(8):199-202.
[23] Ali EM, Ahmed RHA, Ali AMA. Correlation of breast cancer subtypes based on ER, PR and HER2 expression with axillary lymph node status. Cancer and Oncology Research 2014;2(4):51-7.

[24] Azizun-Nisa, Bhurgri Y, Raza F, et al. Comparison of ER, PR and HER2/neu (C-erbB2) reactivity pattern with histologic grade, tumor size and lymph node status in breast cancer. Asian Pac J Cancer Prev 2008;9(4):553-6.

[25] Siadati S, Sharbatdaran M, Nikbakhsh N, et al. Correlation of ER, PR and HER-2/Neu with other prognostic factors in infiltrating ductal carcinoma of breast. Iran J Pathol 2015;10(3):221-6.

[26] Prasad HLK, Rao C, Shetty J. Morphological profile and receptor status in breast carcinoma: an institutional study. Journal of Cancer Research and Therapeutics 2013;9(1):44-9.

[27] Almasri NM, Hamad MA. Immunohistochemical evaluation of human epidermal growth factor receptor 2 and estrogen and progesterone receptors in breast carcinoma in Jordan. Breast Cancer Research 2005;7(5):R598-604.

[28] Idirisinghe PK, Thike AA, Cheok PY, et al. Hormone receptor and c-erbB2 status in distant metastatic and locally recurrent breast cancer. Pathologic correlations and clinical significance. Am J Clin Pathol 2010;133(3):416-29.

[29] Engstrom MJ, Opdahl S, Hagen AI, et al. Molecular subtypes, histopathological grade and survival in a historic cohort of breast cancer patients. Breast Cancer Res Treat 2013;140(3):463-73.

[30] Maha A. Correlation of hormone receptors with HER2/neu protein expression and the histological grade in Invasive breast cancers in a cohort of Saudi Arabia. TJP 2010;26(3):209-15. 